\title{
INTERNATIONAL RESEARCH JOURNAL OF MULTIDISCIPLINARY STUDIES
}

Mobile Librarianship: An Initiative of New Normal

0.679 (IIFS)

\section{Subhajit Panda}

Assistant Librarian, University Library, Chandigarh University (CU)

Email:subhajit.e9641@ cumail.in, Mobile: 8250789798

\begin{abstract}
:
Coronavirus has a clear negative impact on academic and research activities. Issues created by such pandemic e.g. loss of communication; shut down of school, college and universities; disruption of the formal learning process etc provoke us for the transformation of the learning process from conventional to digital. The primary requirement of this transformation is the availability of a sophisticated, affordable and multitasking tool for providing library services. It is now challenging for the libraries to satisfy their user needs and time to rethink and remodel their services by adopting technological changes. Today mobile phones are becoming an integral part of everyday life and are changing the way one connects and interacts with the world. This paper presents an outline of the concept and the application of developments in mobile telecommunication systems, web technologies to provide ubiquitous, user-friendly, personalized and dynamic up to date information services to the users of a library. Also, further studies are expanded to provide insight into the benefits and challenges against the implementation of mobile technologies to support this 'new normal' in the libraries. The practical and theoretical implications of the results have been explored.

Keywords: COVID-19, ICT, Information Management, Mobile Librarianship, Mobile Library Services, Mobile Technology.
\end{abstract}

\section{Introduction:}

Coronavirus [first called 2019-nCoV and officially renamed as SARS-CoV2 (the virus) and COVID-19 (the disease)] (Sarukhan, 2020) is a widespread dangerous disease in recent months, originated in China but with a great impact at the global level. People keep themselves at home to maintain social distancing for reducing the outbreak of community transmission (Panda, 2020). It has a clear negative impact on humanity, including human life, knowledge creation \& information dissemination, as a standard of human development. Some of these challenges are directly or indirectly related to the changing role of librarians and information professionals about providing the right information, at the right time and to the right person, that can solve or reduce some of the challenges. These persons include researcher \& scientists for their research purpose, medical staff $\&$ associate professionals for providing them with up-to-date information, academician \& educators for their teaching purpose, students for their learning purpose and common people for raising awareness. However, because of lockdown and social distancing, there were problems in the process of dissemination of information that is worth considering during this crisis. To adapt this 'new normal' and to fulfil the professional ethics, librarians now try to resolve issues about the interconnection and interoperability of information resources and services. This can be achieved through improvements and refinements of the existing network information service through technologies and infrastructure accompanied by resource aggregation and collaboration. The invention of mobile phones is such a vital achievement of technological developments (S. \& P., 2013). Now mobile technology is playing a very significant role in user's information-seeking behaviour in such a way teaching, learning and research work as per users' need (Singh \& Nikandia, 2017). Libraries being the sanctum sanctorum of any institution of higher education, have always grabbed the opportunity to provide unparalleled initiative and support to the growth of academic institutions (Anbu K, 2016).

\section{Literature Review:}

Here we discussed some prominent literature which visualizes the use \& utilization of mobile tools and technologies to support information generation \& dissemination in the present situation of new normal,

$10^{\text {th }}$ September, 2020

Web: www.irjms.in
Page No: 15

Email: irjms2015@gmail.com, irjms.in@gmail.com 


\section{INTERNATIONAL RESEARCH JOURNAL OF MULTIDISCIPLINARY STUDIES}

Ali \& Bhatti (2020) highlight the important information sources of the Public Health awareness used by the library and information sources in this Pandemic situation. Ali \& Gatiti (2020) explored the role of health science librarians in the coronavirus pandemic included raising awareness through public health education, providing support to medical staff, researchers and providing ongoing traditional services to regular library patrons in Pakistan. Ashrafi-Rizi \& Kazempour (2020) discussed the problems of information generation and dissemination that are worth consideration by analyzed and categorized any kind of information produced and published during the coronavirus crisis. Kari (2020) examined the views of library users and professional regarding the deployment of mobile technologies in libraries by thoroughly tested five hypotheses to achieve the study objectives and a total of 250 librarians and 250 library users purposively selected in Nigeria constituted the sample for the study. Obinyan, (2020) explored in his book chapter about the application of mobile technology on service delivery in libraries, its advantages and disadvantages and also highlighted the skills required by the librarians in incorporating mobile technologies to library services. In his study, Dei (2020) ascertained the potentials of adopting and implementing Mobile Technology ( $\mathrm{m}$-tech) based library services in academic libraries in Ghana using descriptive survey and the mixed-method approach.

\section{Objectives of the Study:}

(i) To discuss in brief about the problems of information generation $\&$ dissemination in the present situation of COVID-19.

(ii) To examine the present situation of Indian Digital Population.

(iii) To show the possible applications of mobile technology in libraries to support .

(iv) To examine the benefits \& limitations of mobile technology in information dissemination in this new normal.

\section{Scope of the Study:}

In the present Coronavirus crisis, it now becomes a huge problem for the library and information professionals in disseminating information to their users. Now librarians become needy for implementing such a technological device which is economical, affordable and can face the challenge of information sharing to the remote user. In this situation, mobile devices and mobile-based library services can be the only solution to meet the needs \& requirements of the users. The safety problems of the users \& library staffs are also taken into the most serious consideration. This paper discusses briefly regarding the core problem arises in the area of information dissemination due to this pandemic, general overview of digital population in India, application of mobile librarianship, its needs, advantages, and drawbacks.

\section{The Statement of the Problem:}

As higher education institutions in India began with strictly follow the guidelines of UGC to respond the COVID-19 pandemic by moving classes, admissions \& evaluation online, and authorizing remote work for educators as well as other staffs of the institution, academic librarians face a huge need of real-time information - not only from the faculty \& staff member but also from the students for completing their semester coursework. For this reason, librarians now try to adapt their own institution's initiatives for new normal, and also how other libraries were responding (Hinchliffe \& Eisenberg, 2020). The loss of proper communication medium \& channel, lockdown \& social distancing, absence of physical presence of library user, disruption of formal library services etc create a need of changes the way of providing library services to its users. And on another side, economical crisis \& cutting budget, unavailability of adequate staff, user awareness etc are the main issues faces by libraries while try to adopt new technologies for accepting the challenges \& issues created by this pandemic. These are challenging economic times for libraries to take on new technological initiatives, yet librarians across the country and

$10^{\text {th }}$ September, 2020

Web: www.irjms.in
Page No: 16

Email: irjms2015@gmail.com, irjms.in@gmail.com 


\section{INTERNATIONAL RESEARCH JOURNAL OF MULTIDISCIPLINARY STUDIES}

(R) MS

ISSN (Online): 2454-8499|

Impact Factor: 1.8167 (GIF), 0.679 (IIFS)

internationally are seeking creative solutions to providing mobile library services (Rahane, 2018). In this point, mobile technology, as an economical \& affordable technological solution that help libraries to keep abreast of the dynamically changing needs of their clientele and identify the way of delivering user-centred services by surveying the user needs.

\section{Mobile Technology in Libraries: Brief Concept}

Yang and Li (2016) observe that the prosperity of the Internet and access to World Wide Web (WWW) especially from the late of 1990s have "completely changed ways of accessing, collecting, organizing, and searching multi-format information in library settings". There is the shift from 'd-learning' (distance learning) to 'e-learning' (electronic learning) and now from 'e-learning' to 'm-learning' (mobile learning) will be the next big wave, which will reform education in India (Vishwakarma, Maurya, \& Govil, 2013).

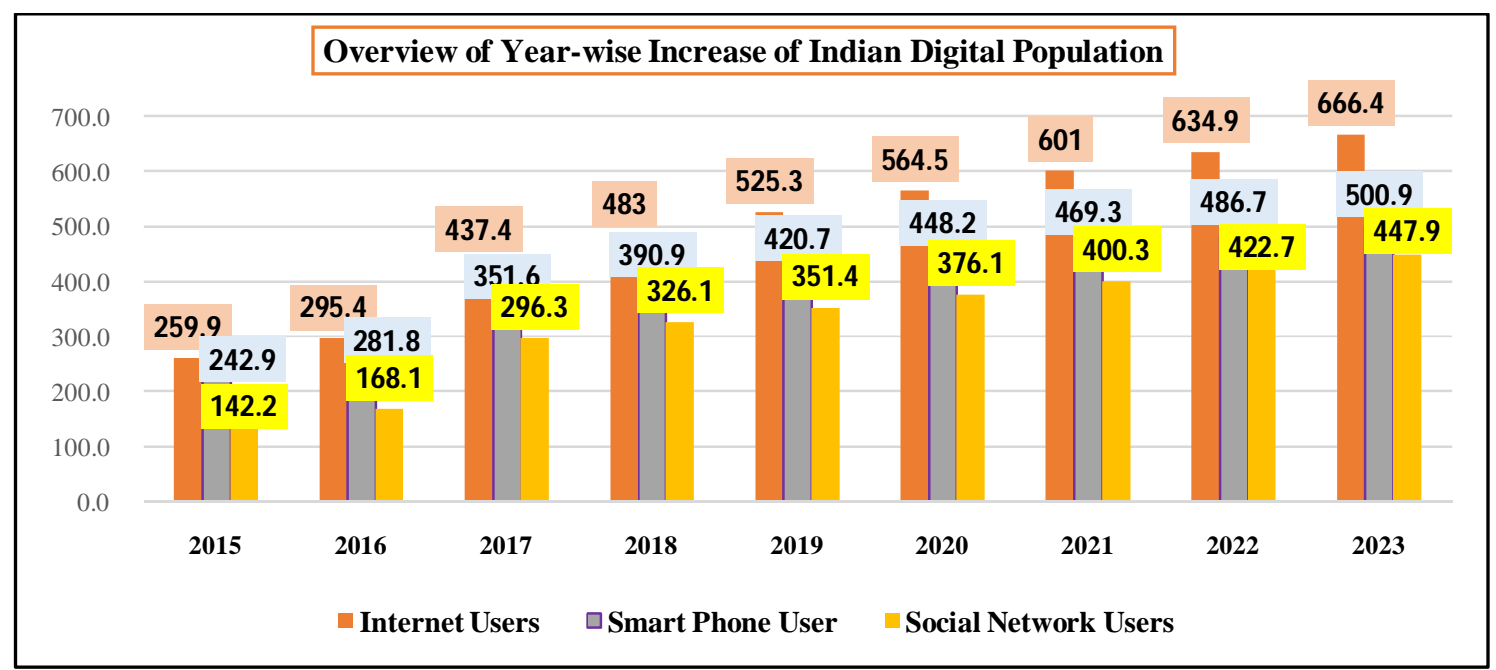

Source: Asher (2020)

Fig 1. Overview of Year-wise Increase of Indian Digital Population (in million)

Mobile must play a key role in enabling Digital India in this situation of 'new normal' by sharing information, encouraging support for social distancing guidelines and helping people to cope emotionally with the changes. It is portable, easy to use and economical for most of the users in India. Connected mobile devices can now connect people and things almost anywhere and anytime. Figure 1 above displays an overview of year-wise increase of Indian digital population from 2015 to assume 2023 considering 'Internet User', 'Smart Phone User' \& 'Social Network User' as parameters. Mobile-based library services helped librarians to well reach out to the remote users who were considered unlikely to connect because of the absence of a medium. Additionally, specialized and personalized information services can be achieved using the wireless technologies made available to all, anytime and anywhere. Mobile devices today can run increasingly complex software, interact with cloud services, play rich multimedia content, and allow for advanced user interactivity. New hardware and technologies such as Bluetooth, accelerometers, and multi-touch screens, as well as text messaging, android phone software applications, mobile websites, global positioning systems (GPS), Wi-Fi, Bluetooth, mobile hotspot, share it, and media creation and capture tools, are all part of the mobile environment (Rahane, 2018).

\section{Application of Mobile Technology in Libraries:}

The COVID-19 (Coronavirus) outbreak is having a global impact, and affecting local communities. Staff in libraries of all types, geographic locations, and sizes are learning the facts about this public health 


\section{INTERNATIONAL RESEARCH JOURNAL OF MULTIDISCIPLINARY STUDIES}

crisis, informing the public, and adapting services and programming to meet changing community needs. In this situation, librarians have to reach user populations and their need for up-to-date relevant information (Okike, 2020).

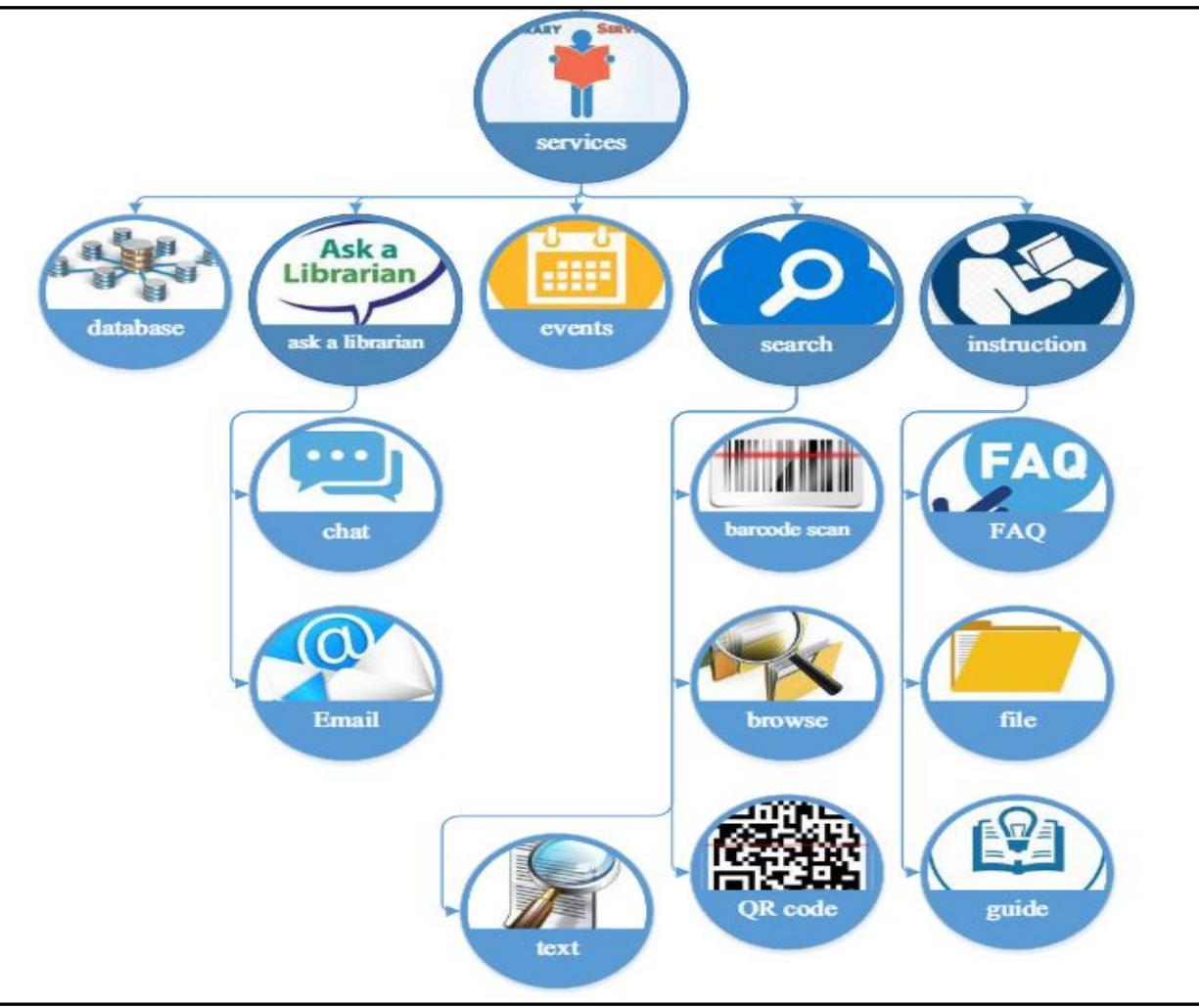

Source: Mansouri \& Soleymani Asl, (2019)

Fig 2. A Prototype Pattern of Library Services via Mobile Applications

Libraries can better serve their users by embracing the growing capabilities of mobile technology. They can promote and expand their existing services by offering mobile access to their websites and online public access catalogues: by supplying on the go mobile reference services: and by providing mobile access to e books, journals, video, audio books, and multimedia content (figure 2). Following are some services which can be provided using mobile tools \& technologies for the benefits of the library users;

\subsection{Virtual Reference Service:}

The restrictions of the present 'new normal' doesn't allow any library user to ask any queries to the reference librarian by physically or face to face meeting, rather the libraries initiated electronic, real-time, \& mobile compatible reference service with proper channel or integration with mobile library website to communicate with reference staff, without being physically present, eg. Ask a Librarian.

\subsection{Library SMS Notifications:}

Obeying the guidelines of pandemic situation, libraries may provide the alerts on the latest news, events and notices via SMS and MMS to users wherever they might be gone. The users can get notified instantly with notice alerts such as- alerts on bringing new books to the notice of users for the suggestion, an intimation of arrival of documents by users, informing availability of reserved documents for collection, appraising about overdue books, outstanding fines, reminders to return library items, renew books, library circulars, e-journals subscribed, change in timings, information about important events etc. Such 


\section{INTERNATIONAL RESEARCH JOURNAL OF MULTIDISCIPLINARY STUDIES}

alert notifications can be generated automatically using an integrated library management system/software or can be sent to a group of users simultaneously through many free applications.

\subsection{Mobile Catalogue(M-OPAC) :}

M-OPAC is the online public access catalogue which is accessible through mobile. It offers a low-cost cloud hosting facilities to all libraries to host their library catalogue in a shared database with their patrons for free and any library can be part of it at low cost. Users can enter various search terms, such as author, subject, keyword, or title to find required resources through M-OPAC. For example, Worldcat Mobile by OCLC, Duke University Library etc.

\subsection{Mobile Circulation:}

Circulation work is a repetitive and time-consuming work in any library. Circulation work can be done easily with the help of a bar code or QR code scanner through a mobile library app. Many mobile apps also come into existence which provides such circulation work through mobile. For example, SirsiDynix PocketCirc is a convenient remote circulation tool that allows the library staff \& library user to access the library material for remote access. It aims to act with prudence to protect the health and safety of library staffs and be proactive to help prevent the spread of COVID-19. With its propensity for person-to-person transmission, SirsiDynix has taken measures to limit non-essential travel for library staffs for eliminating risks of transmission and made remote access available as needed.

\subsection{E-resources with Mobile Interfaces :}

Some publishers already offer e-books (both text and audio) that are accessible through mobile phones to counter this challenging situation. It offers access to a variety of databases and digital resources such as e-Books, e-Journals, Web databases, dissertations, audiobooks, streaming music, films, images and article databases which can be used on mobile. These collections can either be downloaded from the library websites on user's own mobile devices or libraries lend mobile devices with the collections already on them. A large collection of audiobooks both free-and subscription-based services are available for download and also transferable to mobile devices. Libraries may use multimedia messaging service (MMS) on mobile devices to share photos, videos, and audio. Most of the e-book publishers provide $24 \times 7$ access to the library subscriptions from any internet terminal within the campus, as well on mobile devices, such as iPods, Android devices, and Kindle.

\subsection{Quick Response (QR) Codes:}

QR Code is capable to store information (numbers, texts, hyperlinks, contact details, calendar information, e-mail addresses, SMS, maps, etc. Linking to a Web page that allows patrons to locate books nominated for a teen literature prize, vote for their favourite, leave comments, and so forth (figure 5). Librarians can place the codes in the library stacks or magazine/journal areas (figure 3) that point to online electronic holdings of print materials or related subject guides. The code can be embedded to the library website for virtual library tour, access gateway of many publishers site, provide a list of new accessed materials etc (figure 4). Libraries can offer patrons basic information about an item, including the location and call number in catalogue records. Users can scan the code and head to the stacks rather than writing or printing, taping to video/DVD cases, linking to mobile-friendly video trailers. Placing code on staff directory pages and research guides that go to mobile-friendly sites for later reference. Displaying code on study room doors connecting to room reservation forms. 


\section{INTERNATIONAL RESEARCH JOURNAL OF MULTIDISCIPLINARY \\ STUDIES}

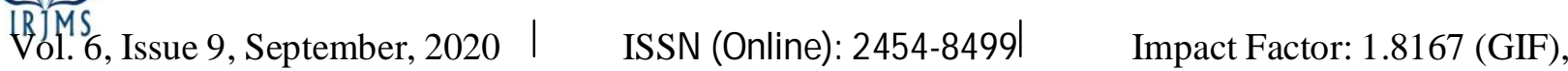

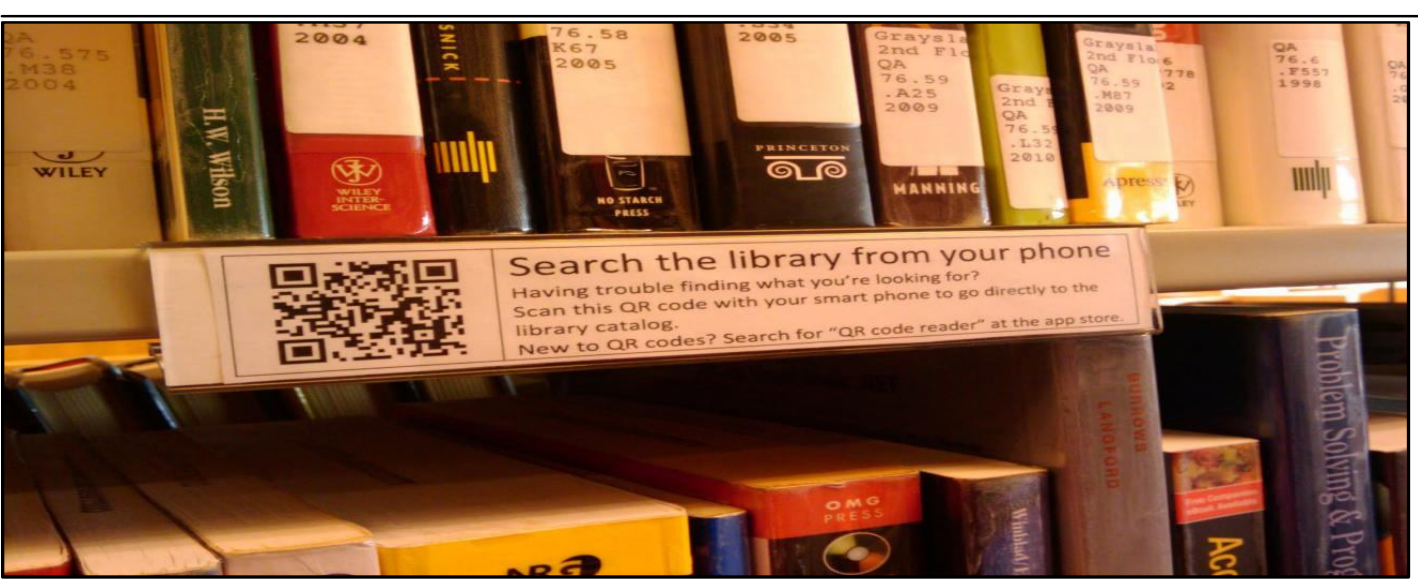

0.679 (IIFS)

Fig 3. QR Code in the Library Stake: Diego State University Library

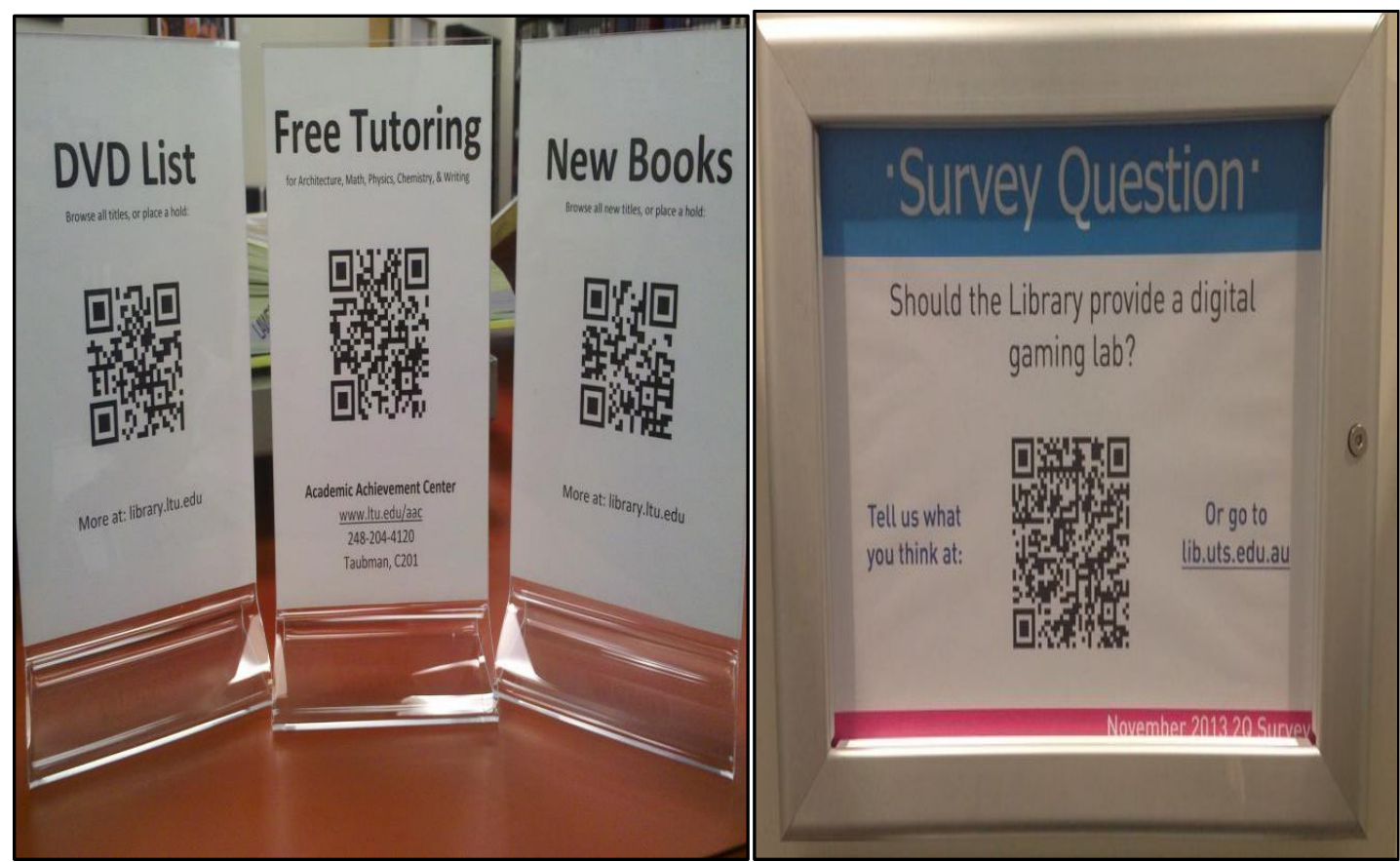

Fig 4. DVD List, Free Tutorial, New Books: Lawrence Technological University Library Fig 5. Survey Questions: University of Technology Sydney (UTS) Library

\subsection{Current Awareness Service (CAS):}

In this challenging situation, CAS has been wide in the role for keeping the users up to date in their areas of interest. The purpose of a current-awareness service is to inform the users about new acquisitions in their libraries. The users can be informed about new arrivals through SMS notifications, social networking sites, email etc. which can be easily accessed through mobiles by the users.

\subsection{Selective Dissemination of Information (SDI):}

SDI is a type of CAS which keeps the users in touch with the latest developments in the field of users' interest or it is a personalized service meant for the individuals or group of users having identical

$10^{\text {th }}$ September, 2020

Web: www.irims.in
Page No: 20

Email: irjms2015@gmail.com, irjms.in@gmail.com 


\section{INTERNATIONAL RESEARCH JOURNAL OF MULTIDISCIPLINARY STUDIES}

information needs. The users can be informed through SMS notifications, social networking sites, email etc. which can be easily accessed through mobiles by the users.

\subsection{Text Reference Service:}

If the library receives a large volume of inquiries requiring brief answers, such as dictionary definitions, details, or service information, then Librarians may provide instant answers and real-time links to articles/references. Researcher, faculty members, students, and academics are now becoming a needy short-range reference inquiry that would be very helpful for mobile-based Text Reference Service.

\subsection{Mobile Document Supply/ Inter Library Loan/ Document Delivery Service:}

Mobile technology present new opportunities for sending document requests and scanned images and monitoring the use of collections as well as the automation of administrative operations. A user can have requested document on his mobile phone via SMS, Email etc.

\subsection{Mobile Printing Service:}

Library can provide user with the facility of printing through their mobile phone for any instant requirement. However, the implementation of this technology is hindered because of its dependence on the capabilities of mobile devices.

\subsection{Information Literacy (IL):}

The outreach programmes of a library face many problems for the outbreak of the recent pandemic. To adapt this 'new normal', libraries will now deliver a variety of instructional programmes that includes curriculum-integrated sessions, multimedia software training, and online learning modules through mobile apps (digital literacy). Faculty may request curriculum-integrated library instruction sessions through mobile apps, training of databases and discovery service use.

\subsection{Mobile Services for Persons with Disabilities:}

The use of the mobile technology in special libraries is beneficial to assist the persons with special abilities like visual or hearing impairments. Such people are often unable to access because there is no special interface for them. Mobile devices such as smartphones which have screen readers that can help the disabled to access information. Visual or vibrating alerts devices, voice recognition and auto text make mobile phones accessible for persons with physical disabilities. For example, LibriVox (Free access to over 24,000 audio books). If any library provide such members with the gateway of LibriVox he can use it through their mobile phone.

\subsection{Mobile Library Website:}

The mobile library website is a preliminary component of m-library services. All the above-mentioned services can be integrated into a single window with the optimization of library website into a mobile-friendly interface via the use of CSS (Cascading Style Sheets) or ADR (Auto-Detect and Reformat Software) which allows it to rearrange its control and navigation to suit the size of the screen it is being viewed on (Maideen, 2017). For example, Cambridge University Library (UK).

\subsection{Mobile Library Apps:}

Mobile applications, apps for short, are dedicated pieces of software or web applications/site that enhance mobile devices capabilities and access information in an elegant, consistent way, and are the means for creating new services for mobile patrons. For example, Duke University Library apps. In the present situation of social distancing and lockdown, mobile library apps can be a useful way to disseminate information to library users. Mobile library apps can also be integrated with main library website.

$10^{\text {th }}$ September, 2020

Web: www.irjms.in
Page No: 21

Email: irjms2015@gmail.com, irjms.in@gmail.com 


\section{INTERNATIONAL RESEARCH JOURNAL OF MULTIDISCIPLINARY \\ STUDIES}

IRJMS 6 , Issue 9, September, 2020 ｜ＩSSN (Online): 2454-8499|Ｉmpact Factor: 1.8167 (GIF), 0.679 (IIFS)

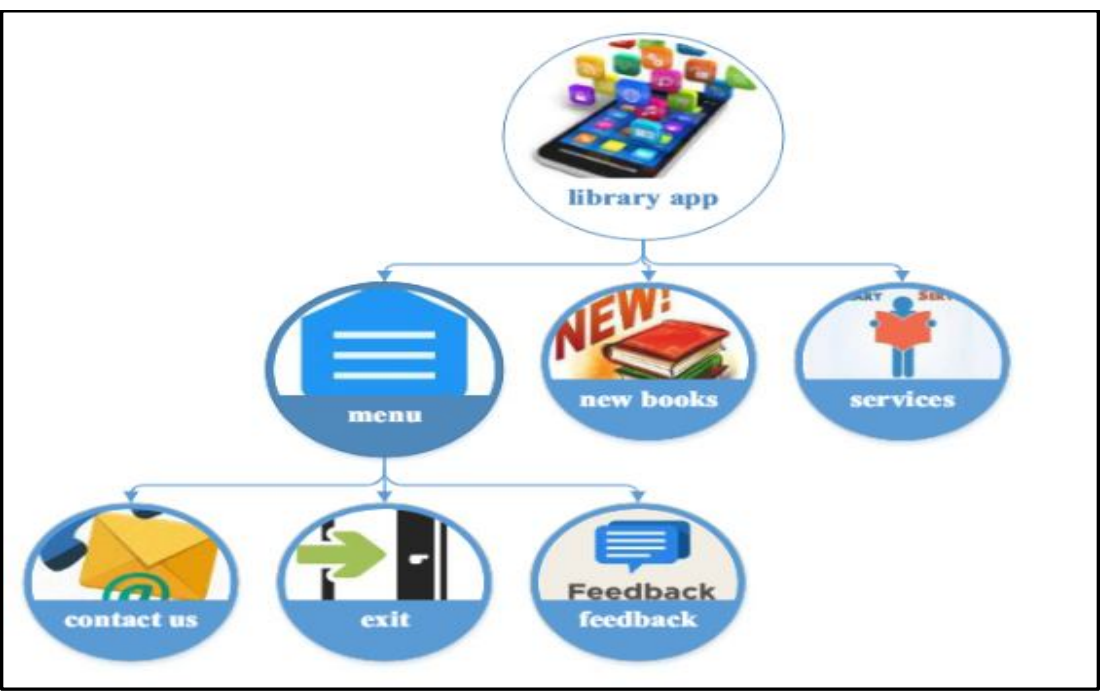

Source: Mansouri \& Soleymani Asl, (2019)

Fig 6. Prototype Pattern of Mobile Library Apps

7.16. Conversational AI with Smart Chatbot:

To provide $24 * 7$ user support without human intervention librarian can refers to the use of messaging apps, voice-based assistants and chatbots to automate communication for personalized user experiences. Conversational interactions support engaging, two-way interactions combined with automation and artificial intelligence (AI) connecting humans and machines through virtual assistants and chatbots (figure 7). The real power of conversational AI lies in its ability to simultaneously carry out highly personalized interactions with large numbers of individual library user.

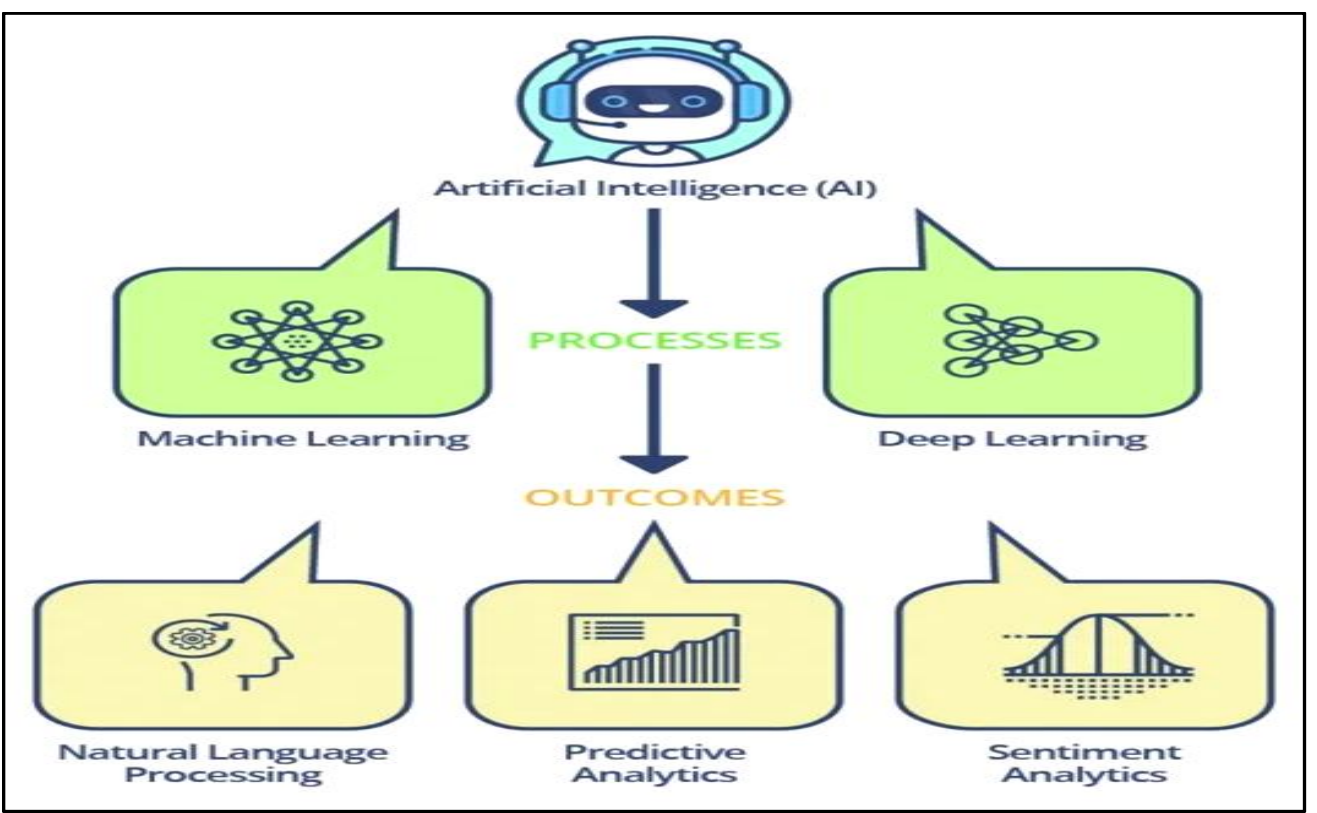

(Source:https://medium.com/marketing-and-entrepreneurship/how-do-chatbots-work-459353cb8895)

Fig 7. Working model of an AI Chatbot

$10^{\text {th }}$ September, 2020

Web: www.irjms.in
Page No: 22

Email: irjms2015@gmail.com, irjms.in@gmail.com 


\subsection{Embedded Librarianship:}

0.679 (IIFS)

Embedded librarians are integrated information experts that offer more direct research assistance to groups of faculty and students than the typical one-shot instruction session, often over an entire semester. The work of Embedded librarians now become more specific \& comfortable due to the help of mobile devices. He/she can now reach to the distance learner with the help of library mobile website or apps and can help every user according to their need.

\subsection{Formal Education, Distance Learning and E-learning}

Libraries can harness the advantage to lead implementation of library services through mobile devices to support distance learning, formal education, and research activities in e-learning environment by making the information resources ubiquitous. Library services should also blend with teaching and research practice of colleges/universities, scientific community or other patrons whom they serve.

\subsection{Social Media:}

The library can use Social media, like, Facebook, Whatsapp, Instagram for the use of updating library users with the current events of the library, e.g. notification about new arrivals, social activities and cultural programme organized by the library, library tour and vacation etc. Social media is an easy platform for the library to connect with its members because it is easily \& freely available for all. Social media also used by the library for marketing purpose.

\subsection{Library Marketing:}

Marketing of library materials, services are needed for user awareness and proper utilization of library materials, which fulfil the laws of library science and meet the information need of the users. For new user online library tours also part of such marketing.

Library marketing can be done using mobile phones through,

- $\quad$ SMS

- Email

- Blogs

- Social Media (Twitter, Youtube, Facebook, Whatsapp etc)

\section{Advantages of Mobile Technology in Libraries:}

Application of mobile phones to provide library services offers new avenues for academic libraries and they can improve the efficiency of library services by communication of information and fast delivery of services to several users at the same time even then they are on move. There are a lot of advantages of application of mobile technology in libraries like:

a) User Friendly: Most of the library users use mobile phones and they easily access web based information provided by their library.

b) Personalized service: In the mobile services users may be categorised in many sections and according to their needs library provides services to them.

c) Saves Time: It saves users time, users need not required to come library, from their mobile phones they can easily access library OPAC to know the status of available resources, reserve their resources, etc.

d) No Geographical restrictions: From any part of the globe they can access the library. Things only needed are an active internet connection, access to library website and a smart mobile phone.

e) Mass Access: A single resource of the library can be accessible from many mobile phones.

f) Active user participation: Through designing of mobile based website, library makes it more interactive by adding chat rooms, blogs, social interface, etc.

$10^{\text {th }}$ September, 2020

Web: www.irjms.in
Page No: 23

Email: irjms2015@gmail.com, irjms.in@gmail.com 


\section{INTERNATIONAL RESEARCH JOURNAL OF MULTIDISCIPLINARY STUDIES}

g) Access management: Through access management library can easily manage to accessibility of library collection.

h) Quick feedback: Through mobile technology users can give quick feedback related to library service and get quick response related to their queries.

\section{Limitations or Barriers of Mobile Technology in Libraries:}

With a lot of benefits there are also some limitations in the application of mobile technology in academic libraries which are discussed as:

a) Less bandwidth speed: In India internet speed on mobiles phones are the major problems. Due to slow downloading and uploading speed users have difficulties in accessing these services from their mobile phones.

b) Initial cost: The initial cost for the installation of these services is quite high and as we all know that libraries depend upon their host institutions.

c) Content ownership, licensing and digital rights management: In the digital era and continue increase in the numbers of users it's very difficult for the libraries to maintain ownership and copyrights of the digital contents. There are many changes in the technology but it's very difficult to control the flow of information.

d) Privacy \& Security: It's very difficult for the libraries to maintain their privacy and security of their resources. Due to mass use of these e-resources the mishandling and miss-use of e-resources such as violation of copyright laws, wrong distribution, modifying, etc are the common things. It is necessary for the libraries to develop tools and techniques to stop such kind of practices.

e) Lack of trained staff: In the field of library and information science there is lack of technically known and skilled staff that can manage and take care of all these things.

f) User education: Users are less aware of how to access and use library resources. They need some kind of user education programme so that they can effectively and efficiently use library services.

\section{Conclusion:}

Due to this recent outbreak of Coronavirus pandemic, the world in which libraries exist has changed dramatically. It moves faster, relies on technology and competes more intensely. Though the use of mobile technology has grown over in the last decade and its uses are going up very fast because it is cheaper than a computer. In this present situation of 'new normal', it supports library to fight against the new challenges in providing adequate library services. A mobile phone is portable, affordable and consist of easy to use technology. The libraries can also implement mobile technology to improve their services and help the librarian to connect with library user anywhere and anytime. It is hoped that from the present study, librarians should implement mobile technology in their respective organization/institution to improve and enhance the library services in this challenging situation so that it is available to users at any place and any time.

"By going mobile, a library takes a giant step toward becoming a round-the-clock service" - Vollmer (2010)

\section{References:}

Ali, M. Y., \& Bhatti, R. (2020). COVID-19 (Coronavirus) Pandemic: Information Sources Channels for the Public Health Awareness. Asia Pacific Journal of Public Health,32(4). https://doi.org/10.1177/1010539520927261

Ali, M. Y., \& Gatiti, P. (2020). The COVID-19 (Coronavirus) Pandemic: Reflections on the Roles of Librarians and Information Professionals. Health Information \& Libraries Journal, 37(2). https://doi.org/10.1111/hir.12307

$10^{\text {th }}$ September, 2020

Web: www.irjms.in
Page No: 24

Email: irjms2015@gmail.com, irjms.in@gmail.com 


\section{INTERNATIONAL RESEARCH JOURNAL OF MULTIDISCIPLINARY STUDIES}

(R)MS

ISSN (Online): 2454-8499|

Impact Factor: 1.8167 (GIF), 0.679 (IIFS)

Anbu K, J. P. (2016). Enhancement of Library Services through Mobile Technology A practical framework (Chapter 1| Library Services through Mobile Technology - An Introduction; pp. 1-34). Retrieved from http://hdl.handle.net/10603/190810

Asher, V. (2020, August 11). Number of smartphone users in India 2015-2023. Retrieved August 25, 2020, from https://bit.ly/31uTqJO

Ashrafi-Rizi, H., \& Kazempour, Z. (2020). Information Typology in Coronavirus (COVID-19) Crisis; a Commentary. Archives of academic emergency medicine, 8(1), e19. https://www.ncbi.nlm.nih.gov/pmc/articles/PMC7075270

Dei, D.-G. J. (2020). Assessing Adoption and Implementation of Mobile Technology-Based Library Services in Academic Libraries. International Journal of Innovative Technology and Exploring Engineering, 9(3), 1669-1677. https://doi.org/10.35940/ijitee.c8305.019320

Hinchliffe, L. J., \& Eisenberg, C. W.-. (2020, March 23). Academic Library Response to COVID-19: Real-Time Data Gathering and Dissemination. Retrieved August 23, 2020, from https://scholarlykitchen.sspnet.org/2020/03/23/academic-library-response-to-covid19/

Kari, H. K. (2020). Libraries and mobile technologies: an assessment of the deployment of mobile technologies in libraries of Nigeria. Skhid, O(1(165)), 41-46. https://doi.org/10.21847/1728-9343.2020.1(165).197402

Maideen, S. (2017). Mobile Technologies for Academic Libraries: An Overview. Emerging Trends in Library and Information Science, 124-129. Retrieved from https://www.researchgate.net/publication/315516134

Mansouri, A., \& Soleymani Asl, N. (2019). Assessing mobile application components in providing library services. The Electronic Library, 37(1), 49-66. https://doi.org/10.1108/el-10-2018-0204

Obinyan, O. O. (2020). Application of Mobile Technologies in Library Service Delivery. In Advances in Library and Information Science (pp. 371-381). https://doi.org/10.4018/978-1-5225-9034-7.ch019

Okike, B. I. (2020). Information dissemination in an era of a pandemic (COVID-19): librarians' role. Library Hi Tech News, ahead-of-print(ahead-of-print). https://doi.org/10.1108/lhtn-04-2020-0040

Panda, S. (2020). A Meta-Analysis of Scholarly Research on Corona virus through Big Data Approach. International Journal of Research in Library Science, 6(2), 66-83. https://doi.org/10.26761/IJRLS.6.2.2020.1339

Rahane, V. C. (2018). Mobile Technology using in Library services. International Journal of Research in Library Science, 4(2), 23. https://doi.org/10.26761/ijrls.4.2.2018.1294

S., M., \& P., K. (2013). Application of Mobile Technologies to Libraries. DESIDOC Journal of Library \& Information Technology, 33(5), 361-366. https://doi.org/https://doi.org/10.14429/djlit.33.5.5098

Singh, K., \& Nikandia, P. K. (2017). Role of Mobile Technology and their Application in Library Services in Digital Era. International Research: Journal of Library and Information Science, 7(1), 157-166. Retrieved from http://irjlis.com/wp-content/uploads/2017/05/11-IR-392.pdf

Vishwakarma, M. L., Maurya, S. L., \& Govil, S. (2013). Use of Mobile and Wireless Technology in Indian Libraries. International Journal Of Engineering And Computer Science, 2(6), 1799-1805. Retrieved from http://www.ijecs.in/index.php/ijecs/article/view/1323/1217

Vollmer, T. (2010). There's an App for That!: Libraries and mobile technology: An introduction to public policy considerations. ALA The Office for Information Technology Policy, 3, 1-18. Retrieved from https://bit.ly/32oAYRw

Yang, S. Q., \& Li, L. (2016). Emerging Technologies for Librarians : a Practical Approach to Innovation (1st ed., p. 2). London, Uk: Chandos Publishing Is An Imprint Of Elsevier.

$10^{\text {th }}$ September, 2020

Web: www.irims.in
Page No: 25

Email: irjms2015@gmail.com, irjms.in@gmail.com 